\title{
Diversity of the var gene family of Indonesian Plasmodium falciparum isolates
}

\author{
Erma Sulistyaningsih ${ }^{1,3}$, Loeki E Fitri ${ }^{2}$, Thomas Löscher ${ }^{3}$ and Nicole Berens-Riha ${ }^{3 *}$
}

\begin{abstract}
Background: The large polymorphic protein PfEMP1 is encoded by the var gene family. PfEMP1 has been shown to play an important role as cytoadherence ligand on the surface of infected erythrocytes and thereby contributes to the distinct pathogenesis of malaria. The study explored the diversity of the DBL1a and DBL2 $\beta-C 2$ domains of the protein from Indonesian Plasmodium falciparum field isolates.

Methods: Samples of patients with severe and uncomplicated malaria from two different malaria-endemic areas in Indonesia were collected and DNA directly extracted. Dried blood on filter paper was prepared for RNA extraction. PCR amplicons were either cloned and subsequently sequenced or directly sequenced for analysis on nucleotide and amino acid level. Recently published as well as self-designed primers were used for amplification.

Results: Blood from eight patients was finally used for analysis. Seventy-one different sequences out of over 500 DBL1a sequenced clones were observed, resulting in an average of 8.9 different DBL1a sequences per isolate. The average DBL1 a sequence similarity within isolates was similar to between isolates. Phylogenetic analysis demonstrated no clustering of sequences regarding strain or geographical origin. The DBL1a sequences were analysed by distribution of semi-conserved features (cysteine/PoLV1-4 grouping) and classified into six sequence groups. The DBL1 a cys2 type was observed in all expressed sequences in vivo. Expression of certain DBL sequences implied potential involvement in the pathogenesis. As expected, the DBL2 $\beta-C 2$ domains showed high to moderate homology among each other.
\end{abstract}

Conclusion: The DBL1 a domains of PfEMP1 from clinical Indonesian isolates showed high divergence among same isolates and some similarities with other Asia-Pacific strains. Further investigations of important var gene domains with a larger sample size are required to confirm with statistical significance observed associations with severe malaria in Indonesian samples.

Keywords: Plasmodium falciparum, var gene, PfEMP1, ICAM-1

\section{Background}

During the erythrocytic cycle, Plasmodium falciparum expresses a protein which is exported from the parasite to the surface of the infected erythrocyte (IE) approximately 18 hours post invasion, called $P$. falciparum erythrocyte membrane protein 1 (PfEMP1). This protein has been linked to two key phenomena responsible for the pathology associated with $P$. falciparum infection: cytoadherence of IE and antigenic variation with consequent immune evasion in the host [1-3]. PfEMP1 is a large and polymorphic protein that varies in domain

\footnotetext{
* Correspondence: berens@|rz.uni-muenchen.de

${ }^{3}$ Department of Tropical Medicine and Infectious Diseases, University of Munich, Munich 80802, Germany

Full list of author information is available at the end of the article
}

composition and binding specificity. It is encoded by the highly diverse var gene family consisting of approximately 60 variable genes per haploid genome of the parasite. Based on chromosomal location, sequence and promoter sequence, the var genes are separated into three major groups (A, B, and C) [4].

Despite their diversity, the majority of var genes contain a number of conserved motifs. Each var gene potentially encodes between two to seven Duffy-binding like (DBL), and cysteine-rich interdomain regions (CIDR). Based on the consensus motifs, DBL domains have been classified into six types; $\alpha, \beta, \gamma, \delta, \varepsilon$, and $\mathrm{x}$ [5]. Specific combinations of domain subtypes are described as short tandem domain cassettes (DC). Rask et al. classified the PfEMP1 protein

\section{Biomed Central}

(c) 2013 Sulistyaningsih et al.; licensee BioMed Central Ltd. This is an Open Access article distributed under the terms of the Creative Commons Attribution License (http://creativecommons.org/licenses/by/2.0), which permits unrestricted use, distribution, and reproduction in any medium, provided the original work is properly cited. 
in 628 homology blocks [6]. Due to high conservation in flanking regions and extreme diversity in the inner parts, the amino-terminal DBL domain, DBL1 $\alpha$, has been the main target for diversity studies [7-12].

The extent of var gene diversity in different geographic regions has previously been reported [10]. Another study investigating DBL1 $\alpha$ sequences of laboratory and field strains showed only $15-20 \%$ amino acid conservation [8]. In general, the average level of DBL1 $\alpha$ sequence variability within isolates was as great as between isolates [7-9]. However, high overlapping of the var gene repertoire in Western Amazon isolates was recently reported $[11,12]$.

The DBL2 $\beta-C 2$ domain mediates binding to the intercellular adhesion molecule 1 (ICAM-1) in several $P$. falciparum isolates. Binding to ICAM-1 seems to play a role in severe disease development. The adhesion to ICAM-1 tended to be higher in patients with cerebral malaria [13]. Further, co-localization of ICAM-1 with parasite sequestration in brain vessels in autopsy samples from cerebral malaria patients [14] and up-regulation of ICAM-1 expression on endothelium during malaria infection was observed [15].

The ICAM- 1 binding seems to require the DBL2 $\beta-C 2$ domain including 16 conserved cysteine residues [16-19], as they contain contact residues for ICAM-1. A truncated analysis demonstrated that the critical ICAM-1 binding regions lie between a conserved tryptophan (W) and the first half of the $\mathrm{C} 2$ part including the ' $\mathrm{Y}$ motif'. However, the optimal binding activity seems to depend on residues in the first part of the DBL $\beta$ [18].

Alignment of ICAM-1 binding DBL2 $\beta-C 2$ domain from three isolates (A4, A4tres and JDP8) revealed significant homology, sharing 16 conserved cysteine residues and a number of conserved hydrophobic amino acid residues. However, multiple alignments of ICAM-1 binding and non-binding DBL2 $\beta-C 2$ domains suggested that the binding region for ICAM-1 is unlikely to lie in a linear sequence stretch within DBL2 $\beta-C 2$ [19].

Recent evidence showed that a conserved ICAM1-binding epitope lies in a subset of group A PfEMP1 domains called DC4 including DBL $\beta$ [20].

Furthermore, an association between var gene expression and severity of malaria has been reported. Studies from Brazil and Mali indicated that expression of DBL1 $\alpha$ lacking one to two cysteine residues was associated with severe non-cerebral malaria [21,22]. A specific motif of amino acids in DBL1 $\alpha$ that is located in a distinct region of receptor interaction was correlated with rosetting and severe malaria (SM) in Ugandan children [23]. Another study found that expression of a specific genotype, referred as var D gene with characteristics of the DBL $\delta$ domain, was associated with the manifestation of SM [24].

In this study, sequence and motif variability of var genes with emphasis on the DBL1 $\alpha$ and DBL2 $\beta-C 2$ domains from field isolates collected in two different malaria endemic areas in Indonesia are reported. An attempt was made to elucidate the association of specific DBL domain expression and the manifestation of SM.

\section{Methods}

\section{Subjects}

Malaria patients were enrolled from the Saiful Anwar Hospital, Malang, and from Pelaihari District, Banjarmasin. All patients were informed of the study and written informed consent was obtained. Inclusion criteria were mono-infection with $P$. falciparum by microscopic examination of thin and thick blood smears stained with Giemsa and malaria exposure in Indonesia. Severe and uncomplicated malaria (UM) were categorized based on the clinical and laboratorial criteria, according to WHO diagnosis of malaria patients [25]. Six ml heparinized blood from each patient was collected. A minimum of 10 drops was spotted on Whatman filter paper (StandardWhatman Cellulose Chromatography paper 3MM). Samples were immediately processed as described below.

The ethical approval was obtained from the Ethical Committee of Medical Research of Brawijaya University, Indonesia.

\section{RNA isolation and CDNA synthesis}

First, cultures of parasitized erythrocytes from the patients were started [26] to gain RNA but abandoned due to laboratory difficulties. Parasites were harvested 18-24 hours post invasion. To investigate the expression in patients directly, total RNA was extracted from dried blood, spotted directly after blood collection on filter paper, using RNeasy Mini Kit (Qiagen). RNA was then reverse transcribed using SuperScript II reverse transcriptase and Oligo-dT primer. The filter paper was dried at room temperature and later stored by $-20^{\circ} \mathrm{C}$. Samples were shipped on dry ice to the Department of Tropical Medicine and Infectious Diseases in Munich where the extraction was performed.

\section{Isolation of genomic DNA}

Genomic DNA (gDNA) was directly isolated from $600 \mu \mathrm{l}$ blood samples obtained from malaria patients by DNA Blood kit (Qiagen) in Indonesia and shipped to the Department of Tropical Medicine and Infectious Diseases on dry ice.

\section{Species differentiation and genotyping}

Species differentiation including $P$. knowlesi was performed by PCR as described earlier [27]. All parasite isolates were genotyped by fragment size analysis generated by amplification of the polymorphic single copy genes merozoite surface protein-1 (MSP-1), merozoite surface protein-2 (MSP-2) and glutamate-rich protein (GLURP). 
PCR was performed as recently described [28]. Diversity among isolates was determined by size difference of amplification products. Genotyping was performed with directly extracted DNA without previous in vitro culturing to avoid selection of specific genotypes [29].

\section{PCR and sequencing of var genes}

DBL1 $\alpha$ domains were amplified from cDNA and gDNA using universal primers $\alpha A F$ and $\alpha B R$ [7]. PCR products were purified using Ultrafree-DA extraction kits (Millipore), cloned into pGEMT-Easy vector (Promega) and transformed into Escherichia coli DH5 $\alpha$ competent cells (Invitrogen) following manufacturers' instructions. Recombinants were selected by blue-white colour screening and sequenced using T7 and SP6 primers with Big Dye Terminator v3.1 cycle sequencing kit (Applied Biosystems 3730 sequencer). 20-30 colonies were picked for plasmid isolation from each plate. Three plates per isolate were prepared.

\section{Classification of the DBL1a sequence tag}

The DBL1 $\alpha$ sequence tag regions start at a DIGDI motif within homology block (HB) d and end at a PQFLR motif within $\mathrm{HB} \mathrm{h}$, according to the classification by Smith et al. [5]. The sequences were classified in six sequence groups based on the number of cysteine residues within the tag region and a set of sequence motifs at four positions of limited variability (PoLV 1-4). The positions within the sequences are fixed in relation to four anchor points as proposed by Bull and colleagues. PoLV1 and PoLV4 were defined in relation to the $5^{\prime}$ and the $3^{\prime}$ ends of the sequence, respectively. PoLV2 and PoLV3 are correlated to a "WW" motif. This classification is referred to as cysteine/ PoLV sequence grouping [30].

The DBL1 $\alpha$ sequence was also characterized by recently described homology blocks (HBs) using the VarDom server [31]. A HB is defined as a member of sequences with similarity to the sequence profile above a certain threshold (9.97) by Rask et al. [6]. Smith's HBs a-j were redefined, i e, as $\mathrm{HBd}=\mathrm{HB} 3$ and $\mathrm{HBh}=\mathrm{HB} 2$.

\section{Identification of DBL2 $\beta-C 2$ domain of each field isolates}

Specific primer for the DBL2 $\beta-C 2$ sequence were designed according to several referred sequences of the DBL2 $\beta-C 2$ domain: JDP8 (AY028643), isolate IT4/24/25 (IT-ICAM var) (AY578326), clone A4 strain IT4/25/5 (L42244.1), clone A4tres isolate IT (AF193424) and FCR3var CSA (AJ133811). The amplified fragments from PCR were purified using Ultrafree-DA extraction kits (Millipore), cloned into the pGEMT-Easy vector (Promega), and transformed into E. coli JM109 competent cells (Promega) following manufacturers' instructions. Recombinants were selected by blue-white colour screening and sequenced using T7 and SP6 primers with Big Dye Terminator v3.1 cycle sequencing kit (Applied Biosystems 3730 sequencer). Primer walking was performed to identify the inner sequences of the DBL2 $\beta-\mathrm{C} 2$ domain from each isolate (Table 1).

\section{Identification of var D-like gene}

To identify a formerly described $\operatorname{var} \mathrm{D}$ gene, first PCR was conducted using UNIEBP primers [24]. Resulting sequences matched partly with the recently published var $\mathrm{D}$ sequence. Specific primers (var-DF: $5^{\prime}$ - AAT TCC T(C/G)A TGA (A/ T)TT TAA (G/A)CG -3' and var-DR: 5' - CAC ATA ACA $\mathrm{T}(\mathrm{T} / \mathrm{C}) \mathrm{C} \mathrm{C}(\mathrm{A} / \mathrm{T}) \mathrm{T}$ TCC A $-3^{\prime}$;) were designed according to the $\sim 525$ bp resulting sequences $(43.7 \%$ for selected matrix sequence) [24]. The cycle condition consisted of an initial denaturation at $94^{\circ} \mathrm{C}$ for $4 \mathrm{~min}$, followed by denaturation at $94^{\circ} \mathrm{C}$ for $60 \mathrm{sec}$, annealing at $40^{\circ}$ for $60 \mathrm{sec}$, and elongation at $72^{\circ} \mathrm{C}$ for $40 \mathrm{sec}$ with 30 cycles. The PCR products were purified using Ultrafree-DA extraction kit and processed for DNA sequencing directly. Each sample was sequenced on both strands.

\section{Sequence analysis}

The nucleotide sequences derived from the field isolates were analysed for sequence similarities by NCBI BLAST [32]. The nucleotide sequences were translated into amino acid sequences using Expasy Translation Tool [33]. Alignment of sequences was performed by ClustalW. Percentage sequence similarity and phylogenetic tree building were carried out using the algorithm in DNASIS MAX version 3.0 based upon a Neighbour-Joining method in a ClustalW program.

\section{Statistical analysis}

The differences between sequence groups were analysed using Fisher's Exact and $\chi^{2}$ - tests with Yates' continuity correction for small values. Where applicable, means with standard deviation (SD) were calculated and student's $t$-test or wilcoxon rank sum (Mann-Whitney) test was applied. Results were considered significant if p-values were $<0.05$. Software used was stata, version 11 .

\section{Results}

Twenty-two Indonesian malaria patients with written informed consent were enrolled in this study, 14 were excluded afterwards due to molecularly confirmed mixed infections [27]. Five severe falciparum malaria patients, hospitalized in the Saiful Anwar Hospital, Malang, and three uncomplicated falciparum malaria patients from Pelaihari District, Banjarmasin, were recruited. All severely ill patients had cerebral malaria, one female was pregnant. Patients had symptoms up to 14 days before they were recruited (Additional file 1). Four SM patients were treated unsuccessfully with chloroquine before admission. 
Table 1 Primer pairs to amplify DBL2 $\beta-C 2$ domain

\begin{tabular}{|c|c|c|}
\hline Primer & Forward & Reverse \\
\hline \multicolumn{3}{|c|}{ Primers to amplify the whole DBL2 $\beta-C 2$ domain } \\
\hline DBLßF-R & 5'-AGT GTG TTG AAG GAC GTA TGT-3' & 5'-CCA AAC ATA TAT CTC TAT AAT CTC C-3' \\
\hline \multicolumn{3}{|c|}{ Primers to amplify the inner sequences of DBL2 $\beta-C 2$ domain (primer walking) } \\
\hline Pap1_DBLß & 5'-ATG ACT GAA TGG GC(C/A) GAA TG-3' & 5'-CAA GAA GTC ATA CAC GGA T-3' \\
\hline Pap2_DBL $\beta$ & 5'-ATG ACT GAA TGG GC(C/A) GAA TG-3' & 5'-TAC ATT CTG GAT CCT CTT C-3' \\
\hline Pap3.1_DBLß & 5'-ATG ACT GAA TGG GC(C/A) GAA TG-3' & 5'-CGTTGACTTGTGTACCACCA-3' \\
\hline Pap3.2_DBLß & 5'-ATG ACT GAA TGG GC(C/A) GAA TG-3' & 5'-ATG CGT CCT TAT ACT CTG G-3' \\
\hline Kal1_DBL $\beta$ & 5'-ATG ACT GAA TGG GC(C/A) GAA TG-3' & 5'-TAG TAC CAC CGA TTG AGC GT-3' \\
\hline Kal2_DBL $\beta$ & 5'-ATG ACT GAA TGG GC(C/A) GAA TG-3' & 5'-TGT TCA TCG TCT TCA CCT T-3' \\
\hline Kal3_DBL $\beta$ & 5'-ATG ACT GAA TGG GC(C/A) GAA TG-3' & 5'-TAG TAC CAC CGA TTG AGC GT-3' \\
\hline Kal4_DBL $\beta$ & 5'-ATG ACT GAA TGG GC(C/A) GAA TG-3' & 5'-TAG TAC CAC CGA TTG AGC GT-3' \\
\hline Kal5_DBL $\beta$ & 5'-ATG ACT GAA TGG GC(C/A) GAA TG-3' & 5'-TAG TAC CAC CGA TTG AGC GT-3' \\
\hline
\end{tabular}

\section{Clonality of field isolates}

For genotyping, the polymorphic regions of MSP-1, MSP2 and GLURP of eight $P$. falciparum isolates were amplified. Multiple fragments were detected from all allelic families as presented in Additional file 2. Ten different bands in the MAD20 allelic family were found, zero to four in each sample; the fragment size ranged from near $160 \mathrm{bp}$ to approximately $350 \mathrm{bp}$. The $\mathrm{K} 1$ allelic family showed four bands between $180 \mathrm{bp}$ to $350 \mathrm{bp}$, each sample presented maximum of two. The RO33 allelic family showed two fragments of approximately $160 \mathrm{bp}$ and 180 bp solely in two samples from Kalimantan. By using MSP-2 genotyping, six different bands of the 3D7/IC family were detected, zero to four in each sample ranging from approximately $400 \mathrm{bp}$ to $800 \mathrm{bp}$. The FC27 family presented 10 different bands, ranging from $270 \mathrm{bp}$ to $600 \mathrm{bp}$, zero to six per sample. One to two bands in each sample were observed by using GLURP specific primers with seven different bands between $600 \mathrm{bp}$ to $1.1 \mathrm{~kb}$. Amplified bands of MSP-1, MSP-2 and GLURP presenting the same fragment size were considered clonally identical. The multiplicity of infection (MOI) is defined as the minimum number of genetically different parasite lines (clones) present in each sample. The MOI of samples ranged from two to 10 parasite lines for each sample (mean 5, SD 2.8) showing a significantly higher MOI in SM (four to 10 parasite lines) than in UM (two to three, $p=0.02$ ). Samples from Papua showed a higher MOI (six to 10) than from South Kalimantan (two to seven, $\mathrm{p}=0.06)$.

\section{DBL1a sequence diversity}

Genomic DNA derived from eight field isolates, 71 different sequences out of a total of over 500 DBL1 $\alpha$ sequences were identified with $<95 \%$ sequence similarity. On average, 8.9 different DBL1 $\alpha$ sequences per isolate were discovered. Accession numbers are given in Additional file 3.
The average DBL1 $\alpha$ amino acid sequence similarity within isolates ranged from $46.9 \pm 5.5$ to $49.4 \pm 5.5$ and among isolates from $47,0 \pm 3.8$ to $52.4 \pm 3.1$. Mean sequence similarity for all samples was $48.3 \pm 7.2$, separation in origin showed similarity of $48.4 \pm 6.6$ and $48.5 \pm 6.4$ for Papua and Kalimantan, respectively. Four DBL1 $\alpha$ sequences were shared between two different isolates, the corresponding isolates came each from the same geographical area, Three sequences were found in isolates from Kalimantan (Kal4.C6 and Kal5.C1; Kal4.B1 and Kal5. A4; Kal1.B7 and Kal5.C3) and one was observed in isolates from Papua (Pap2.A2 and Pap3.A1). In comparison with published sequences, only two sequences from Papua (Pap1.13 and Pap3.C8) showed a $>95 \%$ similarity with isolates from India and Solomon Islands, respectively (Table 2). Phylogenetic analysis demonstrated that there was no clustering of sequences regarding strain or geographical origin (Additional file 4).

\section{Distribution motifs in DBL1a sequences}

Analysis of the six sequence groups of DBL1 $\alpha$ showed group 4 as the most prevalent. Stratification in origin indicated strong evidence for a difference in group $3(\mathrm{p}=0.02)$ and group 4 (0.06). Two third of the Kalimantan sequences belonged to group 4, whereas most of the Papua sequences belonged to group 3 (Figure 1). All sequences of group 3 were obtained from severe cases, otherwise the distribution of sequence groups between isolates causing UM and SM was equal $(\mathrm{p}=0.48)$ (Additional file 5).

Despite the divergence, sequence analysis showed conservation of certain residues in DBL1 $\alpha$ domain. The conserved regions were interspersed with variable blocks and varied in both length and sequence. Similar to the report by Bull and colleagues [30] concerning the association between PoLV motifs and distinct sequence length distributions, sequences containing the MFK* at PoLV1 or the "REY at PoLV2 were associated with short 
Table 2 Amino acid sequence similarities of DBL1a in Indonesian isolates compared to sequences from other countries

\begin{tabular}{|c|c|c|c|c|c|c|c|c|c|c|c|c|c|c|c|c|c|}
\hline & Pap1 & Pap2 & Pap3 & Kal1 & Kal2 & Kal3 & Kal4 & Kal5 & Kenya & Gabon & India & PNG-1 & PNG-2 & Philippines & Solomon & Amazonas & \\
\hline Pap1 & $\begin{array}{l}48.5 \pm \\
6.4\end{array}$ & $\begin{array}{l}48.4 \pm \\
6.6\end{array}$ & $\begin{array}{l}48.6 \pm \\
6.3\end{array}$ & $\begin{array}{l}48.5 \pm \\
6.1\end{array}$ & $\begin{array}{l}48.4 \pm \\
6.2\end{array}$ & $\begin{array}{l}48.3 \pm \\
6.3\end{array}$ & $\begin{array}{l}48.9 \pm \\
6.6\end{array}$ & $\begin{array}{l}48.1 \pm \\
6.7\end{array}$ & $\begin{array}{l}47.3 \pm \\
6.1\end{array}$ & $\begin{array}{l}54.6 \pm \\
6.7\end{array}$ & $\begin{array}{l}50.8 \pm \\
14.0\end{array}$ & $\begin{array}{l}52.7 \pm \\
4.3\end{array}$ & $\begin{array}{l}55.4 \pm \\
8.6\end{array}$ & $48.2 \pm 11.8$ & $46.7 \pm 9.4$ & $44.2 \pm 4.0$ & Pap1 \\
\hline Pap2 & 0 & $\begin{array}{l}48.5 \pm \\
6.4\end{array}$ & $\begin{array}{l}48.6 \pm \\
6.7\end{array}$ & $\begin{array}{l}48.4 \pm \\
6.2\end{array}$ & $\begin{array}{l}48.2 \pm \\
6.6\end{array}$ & $\begin{array}{l}47.9 \pm \\
6.9\end{array}$ & $\begin{array}{l}49.0 \pm \\
7.0\end{array}$ & $\begin{array}{l}47.8 \pm \\
7.3\end{array}$ & $\begin{array}{l}48.4 \pm \\
4.1\end{array}$ & $\begin{array}{l}54.8 \pm \\
4.5\end{array}$ & $48.4 \pm 2.5$ & $\begin{array}{l}50.1 \pm \\
2.0\end{array}$ & $\begin{array}{l}53.6 \pm \\
3.8\end{array}$ & $45.1 \pm 6.0$ & $45.4 \pm 6.1$ & $45.2 \pm 5.1$ & Pap2 \\
\hline Pap3 & 0 & 1 & $\begin{array}{l}48.9 \pm \\
6.3\end{array}$ & $\begin{array}{l}48.6 \pm \\
5.9\end{array}$ & $\begin{array}{l}48.6 \pm \\
6.1\end{array}$ & $\begin{array}{l}48.6 \pm \\
6.2\end{array}$ & $\begin{array}{l}49.2 \pm \\
6.6\end{array}$ & $\begin{array}{l}48.2 \pm \\
6.8\end{array}$ & $\begin{array}{l}47.0 \pm \\
3.8\end{array}$ & $\begin{array}{l}53.9 \pm \\
6.9\end{array}$ & $\begin{array}{l}47.8 \pm \\
11.6\end{array}$ & $\begin{array}{l}51.6 \pm \\
2.7\end{array}$ & $\begin{array}{l}52.9 \pm \\
6.4\end{array}$ & $52.8 \pm 16.6$ & $\begin{array}{l}55.9 \pm \\
22.4\end{array}$ & $44.9 \pm 7.5$ & Рap3 \\
\hline Kal1 & 0 & 0 & 0 & $\begin{array}{l}48.5 \pm \\
5.7\end{array}$ & $\begin{array}{l}48.4 \pm \\
5.7\end{array}$ & $\begin{array}{l}48.3 \pm \\
5.6\end{array}$ & $\begin{array}{l}49.0 \pm \\
6.3\end{array}$ & $\begin{array}{l}48.1 \pm \\
6.3\end{array}$ & $\begin{array}{l}49.4 \pm \\
8.1\end{array}$ & $\begin{array}{l}51.0 \pm \\
5.1\end{array}$ & $44.5 \pm 3.4$ & $\begin{array}{l}50.1 \pm \\
2.2\end{array}$ & $\begin{array}{l}53.7 \pm \\
4.8\end{array}$ & $42.1 \pm 3.8$ & $41.9 \pm 3.9$ & $44.7 \pm 6.4$ & Kal1 \\
\hline Kal2 & 0 & 0 & 0 & 0 & $\begin{array}{l}48.3 \pm \\
5.9\end{array}$ & $\begin{array}{l}48.1 \pm \\
5.8\end{array}$ & $\begin{array}{l}49.1 \pm \\
6.5\end{array}$ & $\begin{array}{l}47.8 \pm \\
6.6\end{array}$ & $\begin{array}{l}47.3 \pm \\
4.5\end{array}$ & $\begin{array}{l}54.0 \pm \\
3.6\end{array}$ & $47.5 \pm 5.8$ & $\begin{array}{l}49.5 \pm \\
3.3\end{array}$ & $\begin{array}{l}55.6 \pm \\
5.8\end{array}$ & $44.3 \pm 8.4$ & $44.1 \pm 7.0$ & $43.1 \pm 5.9$ & $\mathrm{Kal2}$ \\
\hline Kal3 & 0 & 0 & 0 & 0 & 0 & $\begin{array}{l}46.9 \pm \\
5.5\end{array}$ & $\begin{array}{l}49.2 \pm \\
6.7\end{array}$ & $\begin{array}{l}47.3 \pm \\
7.0\end{array}$ & $\begin{array}{l}52.4 \pm \\
3.1\end{array}$ & $\begin{array}{l}54.6 \pm \\
5.5\end{array}$ & $51.1 \pm 2.6$ & $\begin{array}{l}53.5 \pm \\
4.2\end{array}$ & $\begin{array}{l}48.4 \pm \\
2.6\end{array}$ & $49.0 \pm 1.6$ & $48.9 \pm 0.9$ & $53.6 \pm 8.4$ & Kal3 \\
\hline Kal4 & 0 & 0 & 0 & 0 & 0 & 0 & $\begin{array}{l}49.4 \pm \\
6.8 \\
\end{array}$ & $\begin{array}{l}48.7 \pm \\
7.1\end{array}$ & $\begin{array}{l}51.2 \pm \\
3.0\end{array}$ & $\begin{array}{l}52.0 \pm \\
3.3 \\
\end{array}$ & $47.8 \pm 3.1$ & $\begin{array}{l}51.0 \pm \\
4.4\end{array}$ & $\begin{array}{l}54.5 \pm \\
4.2 \\
\end{array}$ & $47.7 \pm 6.9$ & $47.9 \pm 7.7$ & $46.3 \pm 2.8$ & $\mathrm{Kal} 4$ \\
\hline Kal5 & 0 & 0 & 0 & 1 & 0 & 0 & 2 & $\begin{array}{l}47.4 \pm \\
7.4\end{array}$ & $\begin{array}{l}47.6 \pm \\
3.4\end{array}$ & $\begin{array}{l}55.1 \pm \\
5.5\end{array}$ & $48.0 \pm 4.5$ & $\begin{array}{l}52.1 \pm \\
2.6\end{array}$ & $\begin{array}{l}549 \pm \\
7.0\end{array}$ & $44.3 \pm 3.1$ & $44.7 \pm 3.2$ & $48.7 \pm 12.9$ & Kal5 \\
\hline Kenya & 0 & 0 & 0 & 0 & 0 & 0 & 0 & 0 & *** & 41.1 & 44.2 & 51.9 & 44.2 & 46.5 & 46.5 & 43.4 & Kenya \\
\hline Gabon & 0 & 0 & 0 & 0 & 0 & 0 & 0 & 0 & & *** & 60.6 & 52,0 & 63.8 & 44.9 & 44.9 & 38.6 & Gabon \\
\hline India & 1 & 0 & 0 & 0 & 0 & 0 & 0 & 0 & & & $* * *$ & 48.3 & 61.7 & 44.2 & 45 & 40.8 & India \\
\hline PNG-1 & 0 & 0 & 0 & 0 & 0 & 0 & 0 & 0 & & & & $* * *$ & 52.9 & 44.8 & 44.5 & 44.5 & PNG-1 \\
\hline PNG-2 & 0 & 0 & 0 & 0 & 0 & 0 & 0 & 0 & & & & & $* * *$ & 40.4 & 37.5 & 37.5 & PNG-2 \\
\hline Philippines & 0 & 0 & 0 & 0 & 0 & 0 & 0 & 0 & & & & & & $* * *$ & 75,0 & 51.7 & Philippines \\
\hline Solomon & 0 & 0 & 1 & 0 & 0 & 0 & 0 & 0 & & & & & & & $* * *$ & 50.9 & Solomon \\
\hline \multirow[t]{3}{*}{ Amazonas } & 0 & 0 & 0 & 0 & 0 & 0 & 0 & 0 & & & & & & & & $* * *$ & Amazonas \\
\hline & Pap1 & Pap2 & Рap3 & Kal1 & Kal2 & Kal3 & $\mathrm{Kal} 4$ & Kal5 & Kenya & Gabon & India & PNG-1 & PNG-2 & Philippines & Solomon & Amazonas & \\
\hline & Pap1 & Pap2 & Pap3 & Kal1 & Kal2 & Kal3 & $\mathrm{Kal} 4$ & Kal5 & Kenya & Gabon & India & PNG-1 & PNG-2 & Philippines & Solomon & Amazonas & \\
\hline Pap1 & $\begin{array}{l}48.5 \pm \\
6.4\end{array}$ & $\begin{array}{l}48.4 \pm \\
6.6 \\
\end{array}$ & $\begin{array}{l}48.6 \pm \\
6.3 \\
\end{array}$ & $\begin{array}{l}48.5 \pm \\
6.1 \\
\end{array}$ & $\begin{array}{l}48.4 \pm \\
6.2 \\
\end{array}$ & $\begin{array}{l}48.3 \pm \\
6.3 \\
\end{array}$ & $\begin{array}{l}48.9 \pm \\
6.6 \\
\end{array}$ & $\begin{array}{l}48.1 \pm \\
6.7 \\
\end{array}$ & $\begin{array}{l}47.3 \pm \\
6.1 \\
\end{array}$ & $\begin{array}{l}54.6 \pm \\
6.7 \\
\end{array}$ & $\begin{array}{l}50.8 \pm \\
14.0 \\
\end{array}$ & $\begin{array}{l}52.7 \pm \\
4.3 \\
\end{array}$ & $\begin{array}{l}55.4 \pm \\
8.6 \\
\end{array}$ & $48.2 \pm 11.8$ & $46.7 \pm 9.4$ & $44.2 \pm 4.0$ & Pap1 \\
\hline Pap2 & 0 & $\begin{array}{l}48.5 \pm \\
6.4\end{array}$ & $\begin{array}{l}48.6 \pm \\
6.7\end{array}$ & $\begin{array}{l}48.4 \pm \\
6.2\end{array}$ & $\begin{array}{l}48.2 \pm \\
6.6\end{array}$ & $\begin{array}{l}47.9 \pm \\
6.9\end{array}$ & $\begin{array}{l}49.0 \pm \\
7.0\end{array}$ & $\begin{array}{l}47.8 \pm \\
7.3\end{array}$ & $\begin{array}{l}48.4 \pm \\
4.1\end{array}$ & $\begin{array}{l}54.8 \pm \\
4.5\end{array}$ & $48.4 \pm 2.5$ & $\begin{array}{l}50.1 \pm \\
2.0\end{array}$ & $\begin{array}{l}53.6 \pm \\
3.8\end{array}$ & $45.1 \pm 6.0$ & $45.4 \pm 6.1$ & $45.2 \pm 5.1$ & Pap2 \\
\hline Pap3 & 0 & 1 & $\begin{array}{l}48.9 \pm \\
6.3\end{array}$ & $\begin{array}{l}48.6 \pm \\
5.9\end{array}$ & $\begin{array}{l}48.6 \pm \\
6.1\end{array}$ & $\begin{array}{l}48.6 \pm \\
6.2\end{array}$ & $\begin{array}{l}49.2 \pm \\
6.6\end{array}$ & $\begin{array}{l}48.2 \pm \\
6.8\end{array}$ & $\begin{array}{l}47.0 \pm \\
3.8\end{array}$ & $\begin{array}{l}53.9 \pm \\
6.9\end{array}$ & $\begin{array}{l}47.8 \pm \\
11.6\end{array}$ & $\begin{array}{l}51.6 \pm \\
2.7\end{array}$ & $\begin{array}{l}52.9 \pm \\
6.4\end{array}$ & $52.8 \pm 16.6$ & $\begin{array}{l}55.9 \pm \\
22.4\end{array}$ & $44.9 \pm 7.5$ & Рap3 \\
\hline Kal1 & 0 & 0 & 0 & $\begin{array}{l}48.5 \pm \\
5.7 \\
\end{array}$ & $\begin{array}{l}48.4 \pm \\
5.7 \\
\end{array}$ & $\begin{array}{l}48.3 \pm \\
5.6\end{array}$ & $\begin{array}{l}49.0 \pm \\
6.3 \\
\end{array}$ & $\begin{array}{l}48.1 \pm \\
6.3\end{array}$ & $\begin{array}{l}49.4 \pm \\
8.1 \\
\end{array}$ & $\begin{array}{l}51.0 \pm \\
5.1 \\
\end{array}$ & $44.5 \pm 3.4$ & $\begin{array}{l}50.1 \pm \\
2.2 \\
\end{array}$ & $\begin{array}{l}53.7 \pm \\
4.8 \\
\end{array}$ & $42.1 \pm 3.8$ & $41.9 \pm 3.9$ & $44.7 \pm 6.4$ & Kal1 \\
\hline Kal2 & 0 & 0 & 0 & 0 & $\begin{array}{l}48.3 \pm \\
5.9\end{array}$ & $\begin{array}{l}48.1 \pm \\
5.8\end{array}$ & $\begin{array}{l}49.1 \pm \\
6.5\end{array}$ & $\begin{array}{l}47.8 \pm \\
6.6\end{array}$ & $\begin{array}{l}47.3 \pm \\
4.5\end{array}$ & $\begin{array}{l}54.0 \pm \\
3.6\end{array}$ & $47.5 \pm 5.8$ & $\begin{array}{l}49.5 \pm \\
3.3\end{array}$ & $\begin{array}{l}55.6 \pm \\
5.8\end{array}$ & $44.3 \pm 8.4$ & $44.1 \pm 7.0$ & $43.1 \pm 5.9$ & Kal2 \\
\hline Kal3 & 0 & 0 & 0 & 0 & 0 & $\begin{array}{l}46.9 \pm \\
5.5\end{array}$ & $\begin{array}{l}49.2 \pm \\
6.7\end{array}$ & $\begin{array}{l}47.3 \pm \\
7.0\end{array}$ & $\begin{array}{l}52.4 \pm \\
3.1\end{array}$ & $\begin{array}{l}54.6 \pm \\
5.5\end{array}$ & $51.1 \pm 2.6$ & $\begin{array}{l}53.5 \pm \\
4.2\end{array}$ & $\begin{array}{l}48.4 \pm \\
2.6\end{array}$ & $49.0 \pm 1.6$ & $48.9 \pm 0.9$ & $53.6 \pm 8.4$ & Kal3 \\
\hline
\end{tabular}


Table 2 Amino acid sequence similarities of DBL1a in Indonesian isolates compared to sequences from other countries (Continued)

\begin{tabular}{|c|c|c|c|c|c|c|c|c|c|c|c|c|c|c|c|c|c|}
\hline$\overline{\mathrm{Kal}} 4$ & 0 & 0 & 0 & 0 & 0 & 0 & $\begin{array}{l}49.4 \pm \\
6.8\end{array}$ & $\begin{array}{l}48.7 \pm \\
7.1\end{array}$ & $\begin{array}{l}51.2 \pm \\
3.0\end{array}$ & $\begin{array}{l}52.0 \pm \\
3.3\end{array}$ & $47.8 \pm 3.1$ & $\begin{array}{l}51.0 \pm \\
4.4\end{array}$ & $\begin{array}{l}54.5 \pm \\
4.2\end{array}$ & $47.7 \pm 6.9$ & $47.9 \pm 7.7$ & $46.3 \pm 2.8$ & $\mathrm{Kal} 4$ \\
\hline Kal5 & 0 & 0 & 0 & 1 & 0 & 0 & 2 & $\begin{array}{l}47.4 \pm \\
7.4\end{array}$ & $\begin{array}{l}47.6 \pm \\
3.4\end{array}$ & $\begin{array}{l}55.1 \pm \\
5.5\end{array}$ & $48.0 \pm 4.5$ & $\begin{array}{l}52.1 \pm \\
2.6\end{array}$ & $\begin{array}{l}549 \pm \\
7.0\end{array}$ & $44.3 \pm 3.1$ & $44.7 \pm 3.2$ & $48.7 \pm 12.9$ & Kal5 \\
\hline Kenya & & & & & & & & & - & 41.1 & 44.2 & 51.9 & 44.2 & 46.5 & 46.5 & 43.4 & Kenya \\
\hline Gabon & & & & & & & & & & - & 60.6 & 52,0 & 63.8 & 44.9 & 44.9 & 38.6 & Gabon \\
\hline India & & & & & & & & & & & - & 48.3 & 61.7 & 44.2 & 45 & 40.8 & India \\
\hline PNG-1 & & & & & & & & & & & & - & 52.9 & 44.8 & 44.5 & 44.5 & PNG-1 \\
\hline PNG-2 & & & & & & & & & & & & & - & 40.4 & 37.5 & 37.5 & PNG-2 \\
\hline Philippines & & & & & & & & & & & & & & - & 75,0 & 51.7 & Philippines \\
\hline Solomon & & & & & & & & & & & & & & & - & 50.9 & Solomon \\
\hline Amazonas & & & & & & & & & & & & & & & & - & Amazonas \\
\hline & Pap1 & Рap2 & Рар3 & Kal1 & Kal2 & Kal3 & $\mathrm{Kal} 4$ & Kal5 & Kenya & Gabon & India & PNG-1 & PNG-2 & Philippines & Solomon & Amazonas & \\
\hline
\end{tabular}

The table shows in the right upper half means and standard deviations of similarities of pair wise alignments of sequences. All sequences identified per parasite are compared against each other. Several polypeptide sequences from other areas were selected for comparison. The bold numbers in the diagonal show the intra-parasite sequence similarities in the Indonesian samples. In the upper left side, the number of shared sequences ( $>95 \%$ similarity) between the parasite lines are presented. (Accession numbers for sequences used: India: AF404253; Solomon Islands: AY054815; Kenya-Kilifi: AM115931; Papua New Guinea, Madang, Amele (PNG-1): DQ134266; Papua New Guinea (PNG-2): EU787882; Gabon-Bakoumba: DQ135170; Philippines: AY054892). 

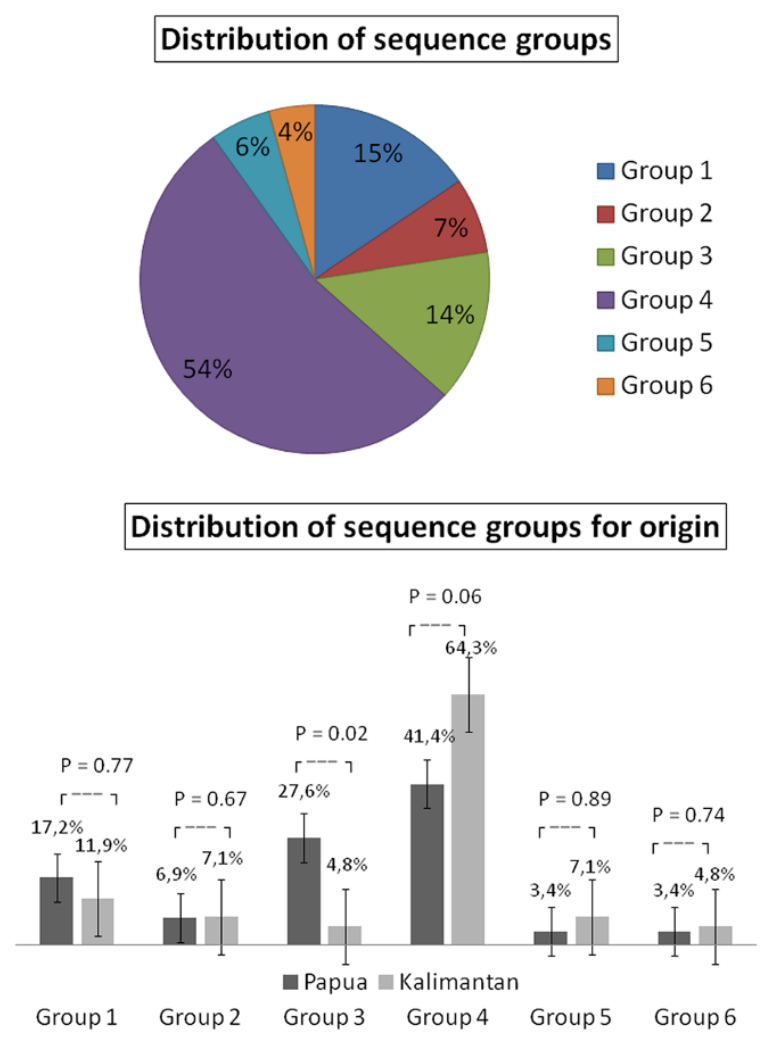

Figure 1 Distribution of DBL1a sequences from gDNA into six sequence groups based on Cystein/PoLV classification. Upper part: The pie chart represents the overall distribution of sequence groups in all 71 sequences from eight isolates. Lower part: Black bars represent DBL1a sequences from isolates from Papua. Grey bars represent DBL1a sequences from Kalimantan. There is statistical evidence for a difference in distribution between the two areas. Group 3 is more prevalent in isolates from Papua. Group 4 is the most prevalent in both areas.

sequences (Figure 2). One motif in each PoLV was revealed as the major motif, i e, LYLG in PoLV1, LRED in PoLV2, KAIT in PoLV3 and PTYF in PoLV4 (Figure 3). Some motifs were detected solely in isolates causing SM or UM (Additional file 5).

Analysis of homology blocks defined by Rask et al. [6] using varDom server showed that the DBL1 $\alpha$ sequences stretched from the most prevalent HB3 to HB2, including subdomain S2b ad S2c. The presence of HB36 in all sequences containing four cysteine residues (cys4) but absence in all sequences containing two cysteine residues (cys2) was also observed as described by Rask and colleagues. HB60 was found in all cys 2 sequences and in 11 (21.6\%) of 51 cys 4 sequences. The same percentage of cys4 sequences presented also HB88 that was absent in cys 2 sequences. HBs $2,3,5,14,54,60,64$, and 131 were found in both sequence types. HB36, HB79, and HB88 could only be detected in cys4 sequences (Additional files 6 and 7).

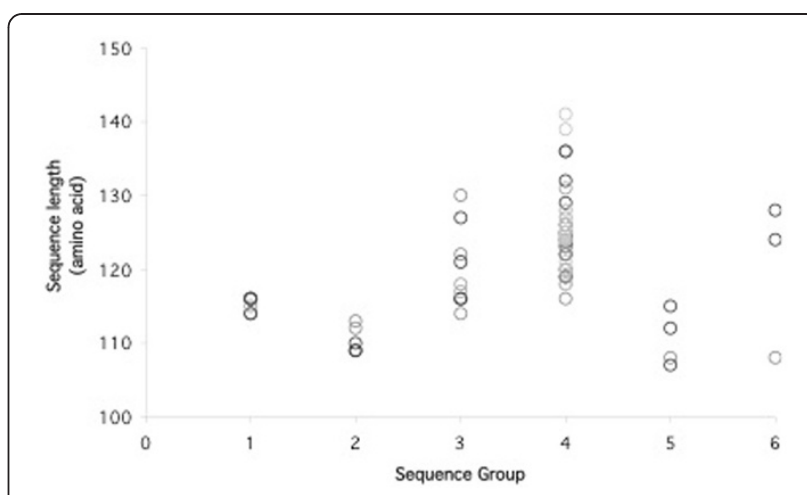

Figure 2 Association between PoLV motifs and distinct sequence length distribution. The graph shows the association between PoLV motifs and distinct sequence length. Sequence group 1,2 and 5 were associated with short sequences. Sequence group 1 contains MFK* at PoLV1 and sequence groups 2 and 5 contain *REY at PoLV2.

\section{Expressed var DBL1a sequence}

In only five (four SM, one UM) of eight samples, an expressed DBL1 $\alpha$ sequence extracted from filter paper was found using $\alpha \mathrm{AF}$ and $\alpha B R$ primers. One of the SM sample was cultivated, synchronized by sorbitol and RNA extracted in trophozoite stage; nine DBL1 $\alpha$ sequences were amplified from the cultured cDNA. Three sequences showed similarities of $97-99 \%$, differing minimally in HB5 and 14 and were considered as the same. MOI of the sample was 6.

Cysteine/PoLV classification analysis of expressed sequences from filter paper showed group 1 and 3 with two cysteine residues (cys2) only, consistent with the presence of HB 60 and absence of HB 36 (Additional file 8).

\section{Identification of DBL2 $\beta-C 2$ domain from field isolates}

Ten different sequences out of 37 sequenced clones were identified. From each sample, at least one DBL2 $\beta-C 2$ sequence was found; Pap2 and Pap3 presented two different DBL2 $\beta-C 2$ sequences. Accession numbers are given in Additional file 3.

DBL2 $\beta-C 2$ sequences from three different samples (Kal1, Kal3, and Kal5) presented more than 99\% sequence similarity; all three samples were originated from the same geographical area but had different clinical manifestations (Figure 4). Nucleotide analysis using NCBI database demonstrated $76-84 \%$ identity with DBL2 $\beta$ domain of PfEMP1 from distinct $P$. falciparum isolates except for Pap2 with 98\% identity with PfEMP1 of IT4/25/5 strain. The amino acid analysis also showed 96\% identity with the PfEMP1 of IT4/25/5 (ID 46361412; acc no. AY578326.1) strain for Pap2 but a range of $44-53 \%$ identity with the PfEMP1 proteins of several $P$. falciparum field isolates.

As previously described by Smith and colleagues [16], the DBL2 $\beta-C 2$ domains except of Kal2.DBL2 $\beta$ shared many 


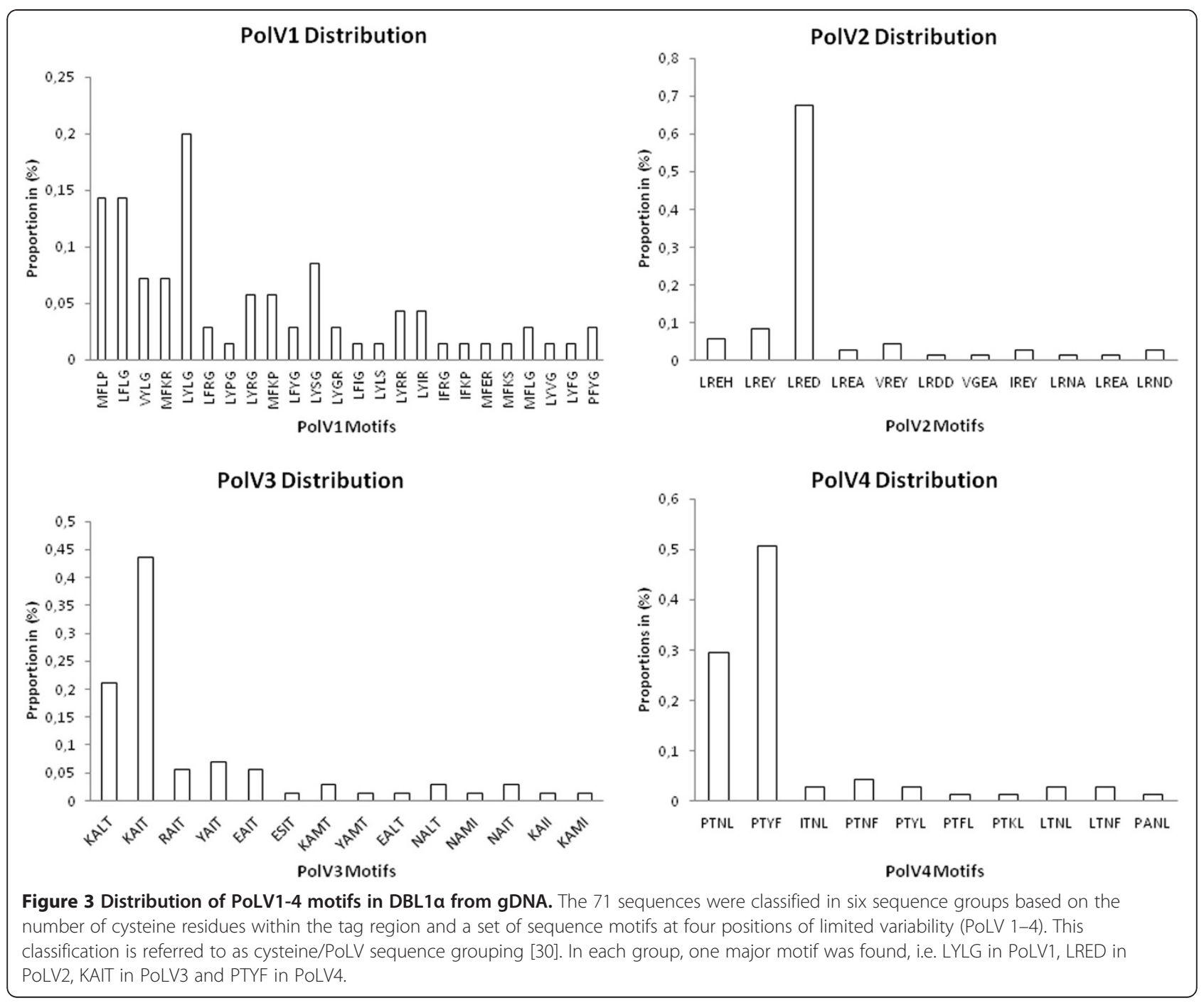

similar features including 16 cysteine residues and blocks of highly conserved amino acids which are flanked by more extensive polymorphic regions (Additional file 9). Compared to other DBL2 $\beta-C 2$ sequences, Kal2.DBL2 $\beta-C 2$ sequence was different; it lacked several conserved cysteine residues, including $\mathrm{C} 6, \mathrm{C} 8-\mathrm{C} 11$ of DBL2 $\beta$ domain and $\mathrm{C} 13, \mathrm{C} 15$ and $\mathrm{C} 16$ of $\mathrm{C} 2$ domain. However, the sequence exhibited the ' $\mathrm{Y}$ motif' within $\mathrm{C} 2$ domain, which was reported to play an important role in binding function of DBL2 $\beta-C 2$ domain. Some DBL2 $\beta-C 2$ sequences also revealed little differences such as one more or less cysteine residue, but all sequences had the ' $\mathrm{Y}$ motif' within the $\mathrm{C} 2$ domain.

Further analysis using varDom 1.0 server showed characteristics of the DBL2 $\beta$ domain for all sequences, though Kal2 was classified as un-type DBL domain (Additional file 10). HB analysis of the DBL2 $\beta$ domain demonstrated the presence of five major HBs (HB1-5) in all sequences
(Additional file 11). Moreover, HB53 in subdomain S1, HB189 in subdomain S2a, HB59 in subdomain S3a and HB61 in subdomain S3b appeared as HB characteristics of the DBL $\beta$ domain.

\section{Identification of var D-like gene}

Amplification using UNIEBP primers from genomic DNA resulted in multiple fragments ranging from nearly $250 \mathrm{bp}$ to $1 \mathrm{~kb}$ in all samples. A fragment of $525 \mathrm{bp}$ was observed in all samples. Specific primers based on this fragment were designed as described previously [24]. The primers yielded multiple fragments from genomic DNA of all eight samples, but generated a single $\sim 237$ bp fragment of cDNA sequences from four SM patients only. The negative SM sample was the same negative with $\alpha \mathrm{AF}$ and $\alpha B R$ primers. Sequence identity to the proposed var D gene [24] was 29.0, 27.8, 27.0 and 19.3\% for var D-like sequence of Kal2, Pap3, Pap1 and Pap2, respectively (Figure 5). 


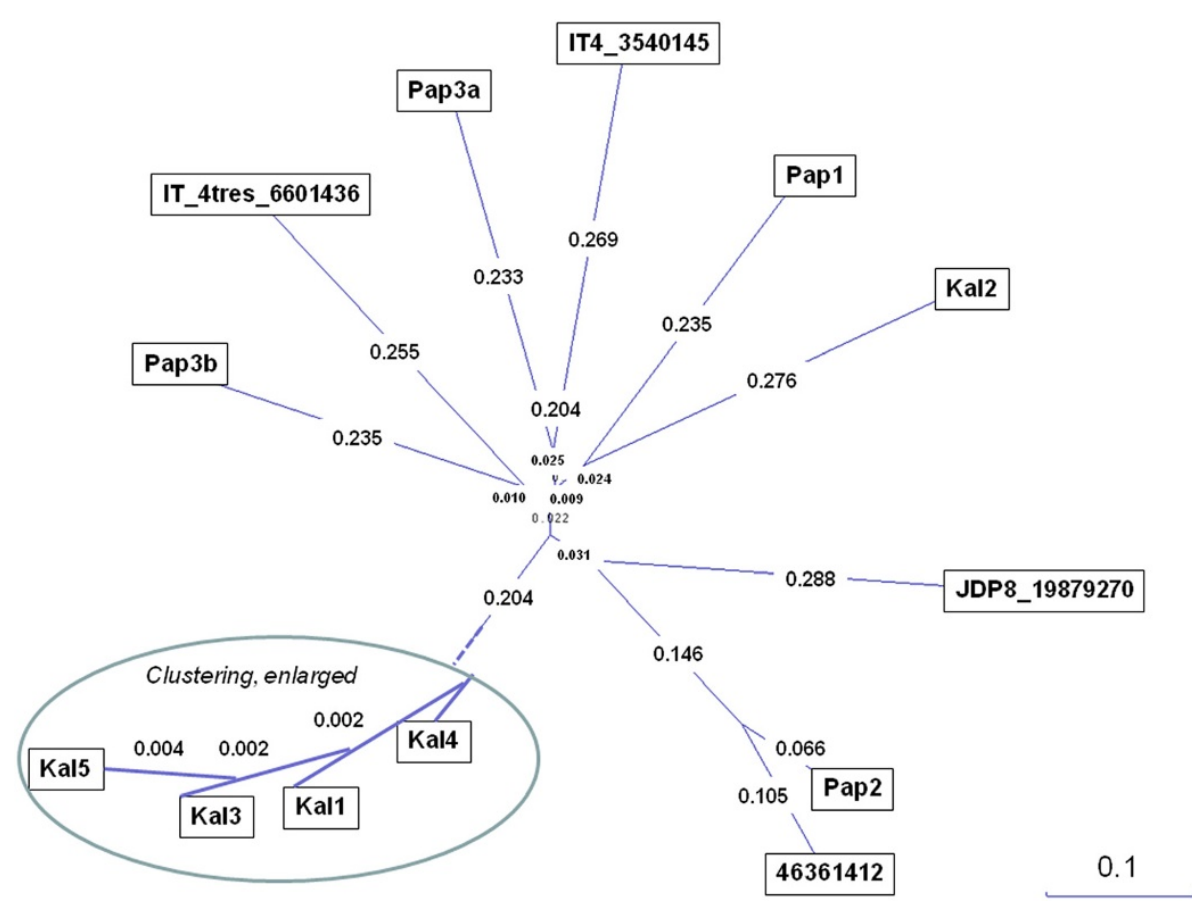

Figure 4 Unrooted phylogram of DBL2 $\beta-C 2$ sequences from Indonesian field isolates and other global isolates using NeighbourJoining method. DBL $\beta-C 2$ sequences from three different samples (Kal1, Kal3, and Kal5) presented more than 99\% sequence similarity. Kal2 showed low homology with the other Kalimantan isolates. Isolates from Papua were diverse. The amino acid analysis showed $96 \%$ identity with the PfEMP1 of IT4/25/5 (ID 46361412; acc no. AY578326.1) strain for Pap2.

Sequences highly matched (80-94\% identity) with the DBLY domain of PfEMP1 from several isolates. However, analysis of homology blocks by using varDom 1.0 server presented homology block (HB) characteristics of DBLY and DBL $\delta$ (Additional file 12). The only conserved structures were HB3 and HB5, one sequence shared HB86 with the proposed var D gene (AJ277137).

\section{Discussion}

This study analysed var genes of $P$. falciparum field isolates derived from two different malaria-endemic areas in Indonesia. Consistent with previous studies on var gene diversity $[3,5,7,8]$, the results demonstrated similar variability of DBL1 $\alpha$ sequences within and between isolates. This implies that the level of diversity represents the overall DBL1 $\alpha$ heterogeneity that exists within each isolate. Regional clustering and conservation like in Amazon isolates was not observed [11,12].

Genotyping results indicated the presence of multiple clones, ranging from two to 10 in each isolate. Patients with SM had significantly more different genotypes than patients with UM. Samples from Papua showed more different clones than those from South Kalimantan. Papua province is an area with stable malaria transmission and a high endemicity class with $\operatorname{PfPR}_{2-10} \geq 40 \%$ [34] resulting in more than one infection per year per individual [35]. In contrast, South Kalimantan Province is a malaria-endemic area with moderate endemicity $\left(5 \%<\operatorname{PfPR}_{2-10}<40 \%\right)$ [34]. Some studies reporting the relationship between the mean number of genotypes per infected person and transmission intensity suggested that an increase in transmission level is proportional to parasite clonality per host [36] and vice versa $[37,38]$.

Barry and colleagues reported on the global diversity in $P$. falciparum var genes from different geographic regions. The diverse repertoire showed spatial structuring but minimal overlap in the var gene repertoire among isolates from different regions, indicating a global distribution of patterns [39]. Data in this study demonstrate little overlap of field isolates from geographically close regions; only four sequences shared similar sequences in isolates from the same area. This is in contrast to the high conservation found in Amazon region mentioned above. As only 8.9 different sequences per isolate were detected, only $15 \%$ of the var gene repertoire was analysed, multi-clonality neglected. Homologies or further differences might be missed.

$86 \%$ of all sequenced genes showed $>95 \%$ similarity to one of the 71 different sequences presented. They belonged each to the same isolate and were considered the same gene. It is possible that some of these sequences were different genes with very similar sequences. However, 


\begin{tabular}{|c|c|c|c|c|c|c|}
\hline & 10 & 20 & 30 & 40 & 50 & 60 \\
\hline Pap 1.varD & AАTTCCTCAT & GATTTTAAGC & GACAAATGTA & TTATAC $\longdiv { T T T }$ & GCTGATTACC & GAGATATATT \\
\hline Pap2.varD & АATTACTCAT & GAATTTAAAA & GACAAATTTA & TTATAC & GGTGATTATA & GAGATA-ATT \\
\hline Pap3.varD & AATTCCTGAA & GATTTTATAC & GTCAAATGTA & TTATAC & GGAGATTATA & GAGATTTATG \\
\hline $\mathrm{Kal2}$ varD & АATTCCTCAT & GATTTTAAGC & GTCAAATGTT & CTATACфTTT & GGAGATTTTA & GAGATTTATG \\
\hline AJ277137 & -- CCCTGAA & GATTTTAAGC & GTCAAATGTT & CTACACфTTT & GGAGATTATA & GAGATTTATG \\
\hline AF547123 & САTTCСTGAA & GGATTTAAAA & GACAAATGTA & TTATAC TTT & GGTGATTATA & GGGATATATT \\
\hline \multirow[t]{2}{*}{$\mathrm{XM} 001351285.1$} & AATTCCAGAA & AATTTTAAAA & GACAAATGTA & TTATAC TTT & GCTGATTACC & GAGATATATT \\
\hline & 70 & 80 & 90 & 100 & 110 & 120 \\
\hline Pap 1.varD & GGAAC & AGATATTACT & TCACATGATC & ATATTCTAGA & TG-TCTCAAA & CAATGC--AA \\
\hline Pap2.varD & FTTTGGGAC & AGATAT---- & $---\cdots-A T C$ & ATCAG----- & --- TGCAAAT & ATT------- \\
\hline Pap3.varD & TTTGGATAA & A.AATAT---- & ---- AGGTA & ATGATGTGAG & TGATGTAGAA & AGT ---- \\
\hline Kal2.varD & TTTGGGTAC & GGATATATCT & GCAAGAAATT & АTССТАTATC & TGATGTTAAA & AAT ---- \\
\hline AJ273137 & TGTGGGTAC & TGATATATCA & AAATTAAATA & CTCACACACA & AGCTGTTAAA & AAT------- \\
\hline AF547123 & -TTTT & AGATATTACT & TCACATGCGA & ATATTCTAGA & GGGTCTCAAA & AAAAGGGTAA \\
\hline \multirow[t]{2}{*}{$\mathrm{XM} 001351285.1$} & TGGAAC & AGATATTACT & TCACATGATC & ATATTCTAGA & TG-TCTCAAA & AAATGC- - AA \\
\hline & 130 & 140 & 150 & 160 & 170 & 180 \\
\hline Pap 1.varD & AAAACAAATT & GAAGGAAAAA & AATGGTAAAC & ACAAAAGTGT & TCCAAAAAAG & GAAGATGAAA \\
\hline Pap2.varD & AAAAGACCT- & ---------- & - ------- & ---------- & TAAATAAA-- - & $--------\mathrm{TA}$ \\
\hline Pap3.varD & AAAATAAAT- & ----- GTAG & TСТTСТСАAА & $\mathrm{A}------\mathrm{GA}$ & TAACAAAACT & GTTAATGGTT \\
\hline Kal2.varD & AATATAGAT- & $------\mathrm{A}-\mathrm{A} \mathrm{A}$ & TGTTTTAATA & AAAACGGTGA & TAAAGGAAAA & AACGATAATA \\
\hline AJ277137 & AATATAGAT- & $----\bar{A}$ GAA & TTTTCTCACC & AAA ---- TGA & TCCAACAAA - - & ---- TGATA \\
\hline AF547123 & AAAAAAAAACT & GAAAGAAAAA & AATGGTGAAC & AAAAAAGTGT & TATAATAATA & GACGATGAAA \\
\hline \multirow[t]{2}{*}{$\mathrm{XM} 001351285.1$} & AAAACAAATT & GAAAGAAAAA & AATGGTGAAC & A.AAAAAGTGT & TATAATAATA & GACGATGAAA \\
\hline & 190 & 200 & 210 & 220 & 230 & 240 \\
\hline Pap 1.varD & AACTGCTTCC & AGA TGGTGG & АATAAACATG & GTCAGGAGAT & ATGGAAAGGA & ATGTTATGTG \\
\hline Pap2.varD & A.A.GACATTT & AAAgGGTGG & GATTCACCTG & GTAAGGAGAT & ATGGAAAGCC & ATGTTACGTG \\
\hline Pap3.varD & TAACACGTGA & AAC TGGTGG & CAAACATATG & GAAAAGATAT & CTGGAAAGGG & ATGGTTTGTG \\
\hline Kal2.varD & CAGAACGTAA & ACA ATGGTG & СAAAAACCTG & GTCCTGAGAT & ATGGAATGGA & ATGTTATGTG \\
\hline AJ 273137 & CAAAACGTAA & \begin{tabular}{l|l} 
AGGATGG & TATTG
\end{tabular} & GA.A.A.A.A.TG & GTCCССTTAT & ATGGCATGGA & ATGTTATGTG \\
\hline AF547123 & AACTGCTTCC & AGA TGGTGG & АATAA.A.CATG & GTAAGGACAT & ATGGGAAGGA & ATGTTATGCG \\
\hline $\mathrm{XM} 001351285.1$ & AATTGCTTGC & AGA TGGTGG & AAAGAACATG & GTCACGAAAT & ATGGGAAGGG & ATGCTCTGTG \\
\hline \multicolumn{7}{|c|}{$\begin{array}{l}\text { Figure } 5 \text { Multiple alignment of specific var D-like sequences. Specific primers designed for the Indonesian var-D like sequence resulted in } \\
\text { sequences corresponding to different sequence types including the DBLy domain of PfEMP-1 isolated from 3D7 [XM_001351285] and patients in } \\
\text { association with PAM [AF547123]. Sequence identity was 29.0,27.8, 27.0 and 19.3\% for Kal2, Pap3, Pap1 and Pap2, respectively, with the } \\
\text { previously reported var D gene (AJ277137). Black boxes: conserved motifs containing of six to } 23 \text { nucleotides. }\end{array}$} \\
\hline
\end{tabular}

this would only enhance the homology rate within an isolate not amongst others. One reason for the limited number of different sequences might be sequence variation at the primer sites in Indonesian samples.

Further analysis using cysteine/PoLV grouping on the distribution motif of DBL1 $\alpha$ sequence tag in association with the geographical origin revealed a similar sequence distribution between isolates, suggesting that although extremely diverse, DBL1 $\alpha$ shares common feature among different geographical origins. Concurred with a previous study which reported a similar distribution of relative number of genomic sequences in each sequence group between field isolates and laboratory isolate 3D7 [40]. The distribution of sequence groups and $\mathrm{HBs}$ of genomic
DNA among isolates was in general equal, indicating that DBL1 $\alpha$ shares common sequences among different clinical categories. Interestingly, group 3 sequences were only found in isolates having caused severe malaria. However, the association lost significance after controlling for origin of the samples; also gDNA lacks information about expression during time of infection. The majority of sequences from both clinical categories belonged to sequence group 4 with four cysteine residues, classified as normal number of cysteine in DBL1 $\alpha$ as described previously [30].

All expressed sequences had two cysteine residues and belonged to sequence group 3 or 1 , in accordance with a report by Kyriacou and colleagues in Malian children 
[21]. However, sample size was too low to differentiate between UM and SM cases.

In this study, the DBL2 $\beta-C 2$ domain of Indonesian $P$. falciparum field isolates was identified. Similar to the previous reports $[16,19]$, multiple alignment analysis showed that the DBL2 $\beta-C 2$ sequences shared many similar features, including 16 conserved cysteine residues (C1-C16) and highly conserved amino acid blocks flanked by more extensive polymorphic regions. A clustering in the Kalimantan isolates was observed whereas the isolates from Papua were more diverse (Figure 4). As only one to two different sequences per isolate were analysed - for further experiments, conclusions are limited.

Ariey et al. reported a specific sequence called var D gene that was expressed in SM. To follow that finding, UNIEBP primers were used. An internal specific primer targeting on var D-like gene according to the amplified fragments was designed. The amplicons derived from RNA corresponded partly to the var D gene reported previously [24] but closely matched with the DBLy domain of PfEMP-1 isolated from 3D7 and patients with placenta-associated malaria from various origins (Figure 5). According to Ariey et al., the var D gene possessed characteristics of the DBL $\delta$ domain, while sequences in this study corresponded to DBLY domain of PfEMP-1. Further analysis found three conserved sequence motifs containing six to 23 nucleotides. Analysis of homology blocks by using varDom server presented homology block (HB) characteristics of DBLy and DBL $\delta$. As only HB3 to HB5 was covered, the origin of the sequences remains uncertain, either DBLy or DBL $\delta$ is possible. Rask and colleagues discussed recombination between and reminiscences of DBL $\gamma$ and DBL $\delta$ domains, which might explain the results [6]. Interestingly, expressed sequences were only found in SM patients.

The low identity of the sequences in this study with the proposed var D gene excludes relatedness. However, the increased prevalence and programmed expression of those sequences containing certain HBs solely in severe malaria implies its possible involvement in pathogenesis of malaria.

\section{Conclusion}

This report on DBL1 $\alpha$ var gene variety in Indonesian isolates with different endemicity and pathology shows the immense diversity of the gene family. DBL $\beta-C 2$ sequences showed regional clustering in Kalimantan isolates and higher conservation than DBL1 $\alpha$ as expected. The prevalence of certain sequences solely in transcripts of SM suggests involvement in the pathogenesis. Based on a larger sample size, further characterization of DBL domains from patients with different clinical manifestations is needed for a thorough analysis of DBL domain expression in falciparum malaria.

\section{Additional files}

Additional file 1: Characteristics of malaria patients. Desription: The table shows gender, age, parasitaemia and clinical outcome of the eight Indonesian patients.

Additional file 2: Genotyping results by MSP-1, MSP-2, and GLURP. Description: The table shows the multiplicity of infection (MOI) of all samples. Severe malaria cases presented with a higher $\mathrm{MOI}$ than those with uncomplicated malaria $(p=0.02)$.

Additional file 3: Accession numbers of DBL1 $\alpha$ and DBL $\beta-C 2$ sequences. Description: The table shows the accession numbers for GenBank, isolate ID, sequence ID and gene of the 71 different DBL1a and 10 differennt DBL $\beta-C 2$ sequences mentioned in this study. Additionally, 22 DBLa sequences with $>95 \%$ similarity to one of the 71 sequences of the same isolate were submitted.

Additional file 4: Unrooted phylogram of DBL1a sequence tags from Indonesian field isolates and other global isolates using NeighbourJoining method. Description: Sequences derived from genomic DNA and cDNA of isolates with severe and uncomplicated malaria. Four pairs of DBL1a sequences showed $>95 \%$ similarity. Sequences from Kal4.C62 and Kal5.C1, Kal4.B12 and Kal5.A4, Kal1.B7 and Kal5.C3 and Pap2.A2 and Pap3. A11 were detected in two different isolates that came from the same geographical area. Two sequences from Papua (Pap1.13 and Pap3.C8) showed a $>95 \%$ similarity with isolates from India and Solomon Islands. Sequences were clustered in separate groups apart from each other, without regarding strain or geographical origin.

Additional file 5: Distribution of sequence groups and motifs from gDNA within isolates causing severe and uncomplicated malaria. Description: Upper part: The graph shows the proportional distribution of sequence groups in the two different clinical categories. Sequence group 3 was only found in isolates causing severe malaria. Lower part: The graph shows the distribution of the 71 sequences classified in the cysteine/PoLV sequence grouping [30]. The six sequence groups are based on the number of cysteine residues within the tag region and a set of sequence motifs at four positions of limited variability (PoLV 1-4). Some motifs were detected solely in severe or uncomplicated malaria.

Additional file 6: Distribution of homology blocks in cys4 sequences from DBL1a domain, classification by Rask et al. using

VarDom server. Description: The table shows the distribution of homology blocks (HB) in DBL1a sequences containing four cysteine residues (cys4) using varDom server. Almost all cys4 sequences contained HB3 and HB5 as major homology blocks. HB36 was present in all cys4 sequences whereas HB60 was found only in 15 of 61 (24.6\%) of cys4 sequences. Sequences from severe malaria cases, gDNA (white letters). Sequences from severe malaria cases, cDNA culture (orange letters). Sequences from uncomplicated malaria cases, gDNA (black letters).

Additional file 7: Distribution of homology blocks in cys2 sequences from DBL1a domain, classification by Rask et al. using VarDom server. Description: The table shows the distribution of homology blocks (HB) in DBL1a sequences containing two cysteine residues (cys2) using varDom server. Almost all cys2 sequences contained HB3 and HB5 as major homology blocks. HB60 was present in all cys2 sequences but no HB36 was found in any cys 2 sequence. HB14 was present in both cys 4 and cys 2 sequences. Sequences from severe malaria cases, gDNA (white letters). Sequences from severe malaria cases, cDNA culture (orange letters). Sequences from severe malaria cases, CDNA filter paper (yellow letters on red). Sequence from an uncomplicated case, cDNA filter paper (yellow letters on black). Sequences from uncomplicated malaria cases, gDNA (black letters).

Additional file 8: Motif distribution of expressed var DBL1a Sequences. Description: The table shows the distribution of expressed var DBL1a sequence motifs (cysteine/PoLV sequence grouping classification by Bull and colleagues). All sequences extracted from blood from filter paper and therefore expressed in the patient during infection showed group 1-3.

Additional file 9: Characteristic of DBL $\beta-C 2$ sequences from field isolates. Description: The graph shows the characteristic of $D B L \beta-C 2$ sequences from Indonesian field isolates. DBL $\beta$ domain of Indonesian 
field isolates shared many similar features including 12 cysteine residues and blocks of highly conserved amino acids flanked by more extensive polymorphic regions. The DBL $\beta$ domain is always followed by $C 2$ domain containing four invariant cysteine residues. The conserved cysteine residues in DBL $\beta-C 2$ are numbered as C1 - C16. The four loops (loop 1-4) and ' $Y$ motif' are indicated by boxes.

\section{Additional file 10: Sequence family classification of DBL $\beta-C 2$} domain from field isolates using varDom server. Description: The table shows the score for sequence family classification of the DBL $\beta-C 2$ domain from field isolates using varDom server. All sequences were classified as Duffy-binding domain with a high score, more than 255.3 (threshold value 9.97), and all sequences except for DBL $\beta$-C2 domain of Kal2 isolate were classified as DBL $\beta$ domain with a score more than 703.1, Kal2_ DBL $\beta-C 2$ domain is a non-typical Duffy binding domain.

\section{Additional file 11: Distribution of five major homology blocks in} DBL $\beta$ domains of field isolates using VarDom server. Description: The table shows the distribution of five major homology blocks (HB1 - HB5) in $D B L \beta$ domains of field isolates using varDom server. All sequences contained five major homology blocks except for Kal2 where HB1 was absent.

\section{Additional file 12: Distribution of homology blocks among the} proposed var D gene using VarDom server. Description: The table shows the distribution of homology blocks (HB) among the proposed var D gene using varDom server. The two motifs HB3 and HB5 seemed to be conserved features. Only one sequence shared HB86 with the previously described var D gene (AJ277137), where HB86 is mainly found in the DBLy domain. Other sequences presented either HB82, HB98, HB27 or HB624. HB82 and HB98 are found in both DBLY and DBL $\delta$, while HB27 is mainly found in DBL $\delta$

\section{Abbreviations}

cDNA: Complementary DNA; CIDR: Cysteine-rich interdomain regions; DBL: Duffy binding-like; EBA: Erythrocytes binding antigen; GLURP: Glutamate-rich protein; ICAM-1: Intercellular adhesion molecule-1; MSP: Merozoite surface protein; TM: Trans-membrane.

\section{Competing interests}

The authors declare that they have no competing interests.

\section{Authors' contributions}

ES conceived the study, performed the laboratory work and the statistical analysis, and wrote the first draft of the manuscript. LEF participated in coordination and collection of samples. TL participated in the design and supervision of study. NBR participated in the design, coordination and analysis of the study and wrote the manuscript. All authors have read the final manuscript and agreed with its contents.

\section{Acknowledgements}

Financial support was granted by the DAAD (PhD scholarship for ES) and the Friedrich Baur Stiftung for consumables. We thank Didi Candradikusuma, Saiful Anwar Hospital, Malang, and Sigit Haryadi, Pelaihari Primary Health Centre, for supporting the sample collection. We also thank the patients for their participation.

\section{Author details}

${ }^{1}$ Faculty of Medicine, University of Jember, Jember 68121, Indonesia. ${ }^{2}$ Faculty of Medicine, Brawijaya University, Malang 65145, Indonesia. ${ }^{3}$ Department of Tropical Medicine and Infectious Diseases, University of Munich, Munich 80802, Germany.

Received: 22 September 2012 Accepted: 19 February 2013

Published: 27 February 2013

\section{References}

1. Su X, Heatwole V, Wertheimer SP, Guinet F. Herrfeld JA, Peterson DS, Ravetch JA, Wellems TE: The large diverse gene family var encodes proteins involved in cytoadherence and antigenic variation of Plasmodium falciparum-infected erythrocytes. Cell 1995, 82:89-100.
2. Baruch DI, Pasloske BL, Singh HB, Bi X, Ma XC, Feldman M, Taraschi TF, Howard RJ: Cloning the $P$. falciparum gene encoding PfEMP1, a malarial variant antigen and adherence receptor on the surface of parasitized human erythrocytes. Cell 1995, 82:77-87.

3. Smith JD, Chitnis CE, Craig AG, Roberts DJ, Hudson-Taylor DE, Peterson DS, Pinches R, Newbold Cl, Miller LH: Switches in expression of Plasmodium falciparum var genes correlate with changes in antigenic and cytoadherent phenotypes of infected erythrocytes. Cell 1995, 82:101-110.

4. Lavstsen T, Salanti A, Jensen TR, Arnot DE, Theander TG: Sub-grouping of Plasmodium falciparum 3D7 var genes based on sequence analysis of coding and non-coding regions. Malar J 2003, 2:27.

5. Smith JD, Subramanian G, Gamain B, Baruch DI, Miller LH: Classification of adhesive domains in the Plasmodium falciparum erythrocyte membrane protein I family. Mol Biochem Parasitol 2000, 110:293-310.

6. Rask TS, Hansen DA, Theander TG, Gorm Pedersen A, Lavstsen T: Plasmodium falciparum erythrocyte membrane protein 1 diversity in seven genomes--divide and conquer. PLoS Comput Biol 2010, 6:e1000933.

7. Taylor HM, Kyes SA, Harris D, Kriek N, Newbold Cl: A study of var gene transcription in vitro using universal var gene primers. Mol Biochem Parasitol 2000, 105:13-23.

8. Ward CP, Clottey GT, Dorris M, Ji DD, Arnot DE: Analysis of Plasmodium falciparum PfEMP-1/var genes suggest that recombination rearranges constrained sequences. Mol Biochem Parasitol 1999, 102:167-177.

9. Kirchgatter K, Mosbach R, del Portillo HA: Plasmodium falciparum: DBL-1 var sequence analysis in field isolates from central Brazil. Exp Parasitol 2000, 95:154-157.

10. Kyes S, Taylor H, Craig A, Marsh K, Newbold C: Genomic representation of var gene sequences in Plasmodium falciparum field isolates from different geographic regions. Mol Biochem Parasitol 1997, 87:235-238.

11. Albrecht L, Merino EF, Hoffmann EH, Ferreira MU, de Mattos Ferreira RG, Osakabe AL, Dalla Martha RC, Ramharter M, Durham AM, Ferreira JE, Del Portillo HA, Wunderlich G: Extense variant gene family repertoire overlap in Western Amazon Plasmodium falciparum isolates. Mol Biochem Parasitol 2006, 150:157-165.

12. Albrecht $L$, Castiñeiras C, Carvalho BO, Ladeia-Andrade S, Santos Da Silva N, Hoffmann EH, Dalla Martha RC, Costa FT, Wunderlich G: The South American Plasmodium falciparum var gene repertoire is limited, highly shared and possibly lacks several antigenic types. Gene 2010, 453:37-44.

13. Newbold C, Warn P, Black G, Berendt A, Craig A, Snow B, Msobo M, Peshu N, Marsh K: Receptor-specific adhesion and clinical disease in Plasmodium falciparum. AmJTrop Med Hyg 1997, 57:389-398.

14. Turner GD, Morrison H, Jones M, Davis TM, Looareesuwan S, Buley ID, Gatter KC, Newbold Cl, Pukritayakamee S, Nagachinta B, White NJ, Berendt AR: An immunohistochenical study of the pathology of fatal malaria. Evidence for widespread endothelial activation and a potential role for intercellular adhesion molecule-1 in cerebral sequestration. Am J Pathol 1994, 145:1057-1069.

15. Turner GD, Ly VC, Nguyen TH, Tran TH, Nguyen HP, Bethell D, Wyllie $S$, Louwrier K, Fox SB, Gatter KC, Day NP, Tran TH, White NJ, Berendt AR: Systemic endothelial activation occurs in both mild and severe malaria. Correlating dermal microvascular endothelial cell phenotype and soluble cell adhesion molecules with disease severity. Am J Pathol 1998, 152:1477-1487.

16. Smith JD, Craig AG, Hudson-Taylor D, Keys S, Fagan T, Pinches R, Baruch DI, Newbold $\mathrm{Cl}$, Miller LH: Identification of a Plasmodium falciparum intercellular adhesion molecule-1 binding domain: a parasite adhesion trait implicated in cerebral malaria. Proc Natl Acad Sci USA 2000, 97:1766-1771.

17. Mayor A, Bir N, Sawhney R, Singh A, Pattnaik P, Singh SK, Sharma A, Chitnis CE: Receptor-binding residues lie in central regions of Duffy-binding-like domains involved in red cell invasion and cytoadherence by malaria parasites. Blood 2005, 105:2557-2563.

18. Springer AL, Smith LM, Mackay DQ, Nelson SO, Smith JD: Functional interdependence of the DBLbeta domain and c2 region for binding of the Plasmodium falciparum variant antigen to ICAM-1. Mol Biochem Parasitol 2004, 137:55-64

19. Chattopadhyay R, Taneja T, Chakrabarti K, Pillai CR, Chitnis CE: Molecular analysis of the cytoadherence phenotype of a Plasmodium falciparum field isolate that binds intercellular adhesion molecule-1. Mol Biochem Parasitol 2000, 13:255-265.

20. Bengtsson A, Joergensen L, Rask TS, Olsen RW, Andersen MA, Turner L, Theander TG, Hviid L, Higgins MK, Craig A, Brown A, Jensen AT: A novel 
domain cassette identifies Plasmodium falciparum PfEMP1 proteins binding ICAM- 1 and is a target of cross-reactive, adhesion-inhibitory antibodies. J Immunol 2013, 190:240-249.

21. Kyriacou HM, Stone GN, Challis RJ, Raza A, Lyke KE, Thera MA: Differential var gene transcription in Plasmodium falciparum isolates from patients with cerebral malaria compared to hyperparasitaemia. Mol Biochem Parasitol 2006, 150:211-218.

22. Kirchgatter $\mathrm{K}$, Portillo HA: Association of severe noncerebral Plasmodium falciparum malaria in Brazil with expressed PfEMPI DBLI alpha sequences lacking cysteine residues. Mol Med 2002, 8:16-23.

23. Normark J, Nilsson D, Ribacke U, Winter G, Moll K, Wheelock CE, Bayaugaba J, Kironde F, Egwang TG, Chen Q, Andersson B, Wahlgren M: PfEMP1DBL1a amino acid motifs in severe disease states of Plasmodium falciparum malaria. Proc Natl Acad Sci USA 2007, 104:15835-15840.

24. Ariey F, Hommel D, Scanf CL, Duchemin JB, Peneau C, Hulin A, Sarthou JL, Reynes JM, Fandeur T, Mercereau_Puijalon O: Association of severe malaria with a specific Plasmodium falciparum genotype in French Guiana. $J$ Infect Dis 2001, 184:237-241.

25. WHO: Severe falciparum malaria. Trans R Soc Trop Med Hyg 2000, 94(Suppl 1):S1-S90.

26. Trager W, Jensen JB: Human malaria parasites in continuous culture. Science 1976, 193:673-675.

27. Sulistyaningsih E, Fitri LE, Löscher T, Berens-Riha N: Diagnostic difficulties with Plasmodium knowlesi infection in humans. Emerg Infect Dis 2010, 16:1033-1034

28. Snounou G: Genotyping of Plasmodium spp. Nested PCR. Methods Mol Med 2002, 72:103-116.

29. Day KP, Koella JC, Nee S, Gupta S, Rad AF: Population genetics and dynamics of Plasmodium falciparum: an ecological view. Parasitology 1992, 104:S35-S52.

30. Bull PC, Kyes S, Buckee CO, Montgomery J, Kortok MM, Newbold Cl, Marsh $\mathrm{K}$ : An approach to classifying sequence tags sampled from Plasmodium falciparum var genes. Mol Biochem Parasitol 2007, 154:98-102.

31. VarDom Server. www.cbs.dtu.dk/services/VarDom/.

32. NBCI BLAST Tool. www.ncbi.nlm.nih.gov/Blast.cgi.

33. Expasy Translation Tool. www.expasy.ch/tools/dna.html.

34. Elyazar IRF, Gething PW, Patil AP, Rogayah H, Kusriastuti R, Wismarini DM Tarmizi SN, Baird JK, Hay SI: Plasmodium falciparum malaria endemicity in Indonesia in 2010. PLoS One 2011, 6:e21315.

35. Karyana M, Burdarm L, Yeung S, Kenangalem E, Wariker N, Maristela R, Umana KG, Vemuri R, Okoseray MJ, Pettinen PM, Ebsworth P, Sugiarto P, Anstey NM, Tjitra E, Price RN: Malaria morbidity in Papua Indonesia, an area with multidrug resistant Plasmodium vivax and Plasmodium falciparum. Malar J 2008, 7:148.

36. Appawu M, Owusu-Agyei S, Dadzie S, Asoala V, Anto F, Koram K, Rogers W Nkrumah F, Hoffman SL, Fryauff DJ: Malaria transmission dynamics at a site in northern Ghana proposed for testing malaria vaccines. Trop Med Int Health 2004, 9:164-70

37. Paul REL, Hackford I, Brockman A, Muller-Graf C, Price R, Luxemburger C, White NJ, Nosten F, Day KP: Transmission Intensity and Plasmodium falciparum Diversity on the Northwestern Border of Thailand. Am J Trop Med Hyg 1998, 58:195-203.

38. Paul REL, Packer MJ, Walmsley M, Lagog M, Ranford-Cart-wright LC, Paru R, Day KP: Mating patterns in malaria parasite populations of Papua New Guinea. Science 1995, 265:1709-1711.

39. Barry AE, Leliwa-Sytek A, Tavul L, Imrie H, Migot-Nabias F, Brown SM, McVea GAV, Day KP: Population genomic of the immune evasion (var) genes of Plasmodium falciparum. PLoS Pathog 2007, 3:e34.

40. Bull PC, Berriman M, Keys S, Quail MA, Hall N, Kortok MM, Marsh K, Newbold $\mathrm{Cl}$ : Plasmodium falciparum variant surface antigen expression pattern during malaria. PLOS Pathog 2005, 1:e26.

doi:10.1186/1475-2875-12-80

Cite this article as: Sulistyaningsih et al: Diversity of the var gene family of Indonesian Plasmodium falciparum isolates. Malaria Journal 2013 12:80.

\section{Submit your next manuscript to BioMed Central and take full advantage of:}

- Convenient online submission

- Thorough peer review

- No space constraints or color figure charges

- Immediate publication on acceptance

- Inclusion in PubMed, CAS, Scopus and Google Scholar

- Research which is freely available for redistribution 